\title{
Nevroner og transcendens
}

Livsvitenskapens utfordringer til filosofi og teologi

Marius Timmann Mjaaland, Dr. theol., Mag.art. i filosofi. Professor i religionsfilosofi ved Det teologiske fakultet, Universitetet i Oslo, Pb. 1023 Blindern, 0315 Oslo

m.t.mjaaland@teologi.uio.no

Nevrovitenskapen har gjort store fremskritt de siste årene. Men nye oppdagelser reiser også nye filosofiske og teologiske problemer: Hvordan skal vi forstå tid og rom, bevissthet og mening - og hvordan skal vi tenke om religiøse erfaringer og erkjennelse av Gud - hvis vår oppfattelse og forklaring av verden primært defineres av det nye paradigmet, med vekt på nevroner og synapser? Et nøkkelspørsmål blir hvordan vi kan forklare transcendens erfaringer knyttet til oppfattelsen av tid og rom i og gjennom nevronene.

Den rivende utviklingen innen nevrovitenskapen de siste femti årene har ikke først og fremst vært drevet frem av filosofiske perspektiver. Ifølge hjerneforskeren Eric Kandel, som fikk Nobelprisen i 2000, har den tvert imot funnet sted på tross av filosofien ved at den ganske enkelt har gitt bedre og enklere forklaringer på fenomener som filosofene de siste to og et halvt årtusen har fors $\varnothing \mathrm{kt}$ å forstå gjennom et stadig mer sofistikert begrepsapparat, gjennom ontologi og erkjennelsesteori, religions- og språkfilosofi. ' Men der vi tidligere prøvde å forstå og tyde, har vi ifølge Kandel nå fått en vitenskapelig etterprøvbar forklaring på hvordan mennesker oppfatter verden, og hvordan vi organiserer og lagrer disse inntrykkene i hukommelsen, som kan lokaliseres til bestemte celler og synapser i hjernen. Hukommelse, bevissthet, tro, sanseinntrykk - alt dette kan nå observeres i laboratoriet og etterprøves eksperimentelt. Derfor mener nevrobiologen Kandel at vi for første gang har en vitenskapelig forklaring på et nivå som de klassiske filosofene, inkludert Descartes, Hume og Kant, ikke engang var i nærheten av.

\section{Ny forståelse av virkeligheten?}

Har Kandel rett? Er det slik at nevro- og livsvitenskapene (life science) gir oss en helt ny og mer vitenskapelig forståelse av virkeligheten, ja - av livet selv, basert på forklaring og fors $\varnothing k$, ikke på beskrivelser og spekulasjon? Kan vi kaste den gamle filosofien på båten og fra nå av basere oss på kunnskapen vi får fra livsvitenskapene? Eller må det utvikles en ny filosofi på nye premisser? I filosofi og annen humanistisk forskning fins det tre typer svar på disse spørsmålene, grovt sammenfattet som «ja», «nei» og «kanskje» (eller «delvis»):

(i) Den første typen svar kan karakteriseres som naturalistisk, ofte i form av analytisk nevrofilosofi. Den er begeistret over den nye innsikten og legger seg gjerne tett opp til nevrovitenskapens resultater fra laboratoriet, men søker å systematisere disse resultatene ut fra en helhetlig modell. Det kommer i dag bidrag til nevrofilosofien fra store deler av verden, men noen av de viktigste forskerne på feltet er amerikanerne Daniel Dennett, Patricia Churchland og Paul Churchland. .i Som representanter for analytisk nevrofilosofi er det disse tre jeg primært vil referere til her. 
(ii) Den andre typen reaksjon innebærer generelt sett en avvisning av problemstillingen som reduksjonisme. En anerkjenner kanskje at nevrovitenskapen er viktig, men det er primært et teknisk spørsmål om hjernens utvikling som ikke endrer premissene for filosofisk praksis. Blant kritikerne av reduksjonismen finner vi filosofer som Thomas Nagel og David Chalmers. iii John Searle har argumentert for at Dennett begår et grunnleggende kategorimistak. ${ }^{\mathrm{iv}}$ Ingen av disse avviser riktignok relevansen av nevrovitenskap for filosofien, men de avviser reduksjonismen og hevder at det filosofiske problemet om bevissthet ikke kan reduseres til materialisme og naturalisme. Filosofien møter nye utfordringer med å forstå forholdet mellom bevissthet og hjerne, men problemstillingene forblir relativt uforandret.

(iii) En tredje reaksjon har de siste årene utviklet seg innenfor fenomenologien, som relativt sent har tatt utfordringen fra nevrovitenskapen. Her har filosofer som Shaun Gallagher og Dan Zahavi tatt til orde for en nevrofenomenologi, som ikke reduserer bevisstheten til materie, men som fors $\varnothing$ ker å forstå livsvitenskapens resultater fenomenologisk, altså under forutsetning av at mennesket heller ikke kan oppfatte og forstå noe som helst uten å gjøre det fra sitt subjektive perspektiv. ${ }^{v}$ Samtidig argumenterer en annen filosof og fenomenolog, Cathérine Malabou, for at dette innebærer en liten revolusjon for erkjennelsesteorien: Også premissene for filosofisk refleksjon må gjennomtenkes på nytt. vi

I denne artikkelen skal jeg fokusere på spørsmålet om tid og rom, et av de virkelig gamle filosofiske spørsmålene. Hva er tid?, spør både Aristoteles og Augustin. Sistnevnte undrer seg over at tidsord er blant de aller vanligste, de han er mest fortrolig med, og likevel: "Hvis ingen spør meg, så vet jeg det. Men hvis jeg ville forklare til en som spør meg, så vet jeg ganske enkelt ikke.»vii

Spørsmålene jeg skal fokusere på, er kanskje like uutgrunnelige, men ikke like poetiske: (i) Hvordan utfordrer nevro- og livsvitenskapens forklaring på grunnleggende spørsmål som tid og rom den mer tradisjonelle filosofien, særlig Kants transcendentalfilosofi? (ii) Hvilke nye problemstillinger reiser livsvitenskapen innenfor teologi og religionsfilosofi?

Jeg vil gi en relativt kortfattet presentasjon av noen helt grunnleggende trekk ved hjerneforskningens forståelse av hvordan nerveceller fungerer for vår oppfattelse av tid og rom, for så å vise hvordan kontrasten mellom analytisk og fenomenologisk nevrofilosofi fører til helt ulike fortolkninger av denne kunnskapen. Dernest vil jeg gå litt mer detaljert inn i en viktig ny oppdagelse i hjerneforskningen de siste årene, oppdagelsen av såkalte gridceller - også kalt hjernens GPS - som gjør det mulig for et dyr eller menneske å orientere seg i rommet og huske koordinater for senere. Dette reiser, som hjerneforskeren John O’Keefe har pekt på, noen interessante problemstillinger som går tilbake til Kants forståelse av nettopp tid og rom. Dette eksemplet viser også hvor viktig skillet mellom analytisk og fenomenologisk tilnærming blir for vår forståelse av hjernen og basale kategorier som tid og rom. I lys av dette siste spørsmålet vil jeg trekke frem noen grunnleggende konsekvenser av 
hjerneforskningen for forståelsen av religion generelt og teologi spesielt. Her åpner det seg nemlig noen svært interessante perspektiver for videre refleksjon.

\section{Hjernens oppfattelse av tid og rom}

Spørsmålet om hvordan hjernen oppfatter og organiserer rom og tid, knyttet til såkalte sted-, grid- og tidsceller, har spilt en sentral rolle innenfor nevrovitenskap de siste tiårene. Disse cellene er selvsagt viktige for å forstå hvordan et dyr eller menneske kan orientere seg i verden, men filosofisk sett er de også helt avgjørende for hvordan vi oppfatter virkeligheten i tid og rom. Oppdagelsen av sted- og gridcellene og utforskningen av deres funksjon var begrunnelsen for at John O'Keefe fikk Nobelprisen i medisin eller fysiologi i 2014 sammen med May-Britt og Edvard Moser. Også andre norske hjerneforskere bidro med viktige artikler til nettopp denne oppdagelsen. ${ }^{\text {viii ix }}$

Frem til 1971 var det et mysterium selv for hjerneforskere hvordan dyr og mennesker er i stand til å orientere seg i et ukjent område og lagre denne kunnskapen i hjernen. Men i 1971 lanserte O'Keefe teorien om at vi har bestemte stedceller som kobler sammen informasjon om hvor man er og hva som skjer, og at det måtte være mulig å identifisere stedceller i hippocampus. ${ }^{x}$ Han mente også at disse cellene må romme koder for våre selvbiografiske minner i en kontekst av tid og rom. Teorien ble møtt med sterke motforestillinger, men fikk etter hvert st $\varnothing$ tte fra fors $\varnothing \mathrm{k}$ i laboratoriet: Bestemte celler avfyres på bestemte steder $\mathrm{i}$ rottenes bevegelsesm $\varnothing$ nstre - og dette gjentar seg når rottene vender tilbake til samme sted.

I videre forstand handler denne forskningen om å forstå hjernens biologiske minne. ${ }^{\mathrm{x}}$ Forskere har brukt mye tid på å studere enklere organismer, fremfor alt sneglen aplysia og fruktfluen drosophila, som har en mer oversiktlig genetisk struktur. ${ }^{\text {xii }}$ Dermed kunne man også koble gener direkte til celler og celler til ulike funksjoner i hjernen og i organismen som helhet. Evolusjonsteorien ligger til grunn for at man tenker at det er mulig å dra slutninger fra fruktfluer til mus og rotter og videre til mennesker. Menneskehjernen er annerledes og atskillig mer kompleks, men bestemte funksjoner er det likevel mulig å kjenne igjen, for eksempel i rottenes hippocampus, og knytte til tilsvarende strukturer i våre hjerner.

Bak denne kunnskapen åpner det seg en avgrunn av filosofiske perspektiver, som O'Keefe slett ikke var fremmed for: Hva er tid? Hva er rom? Hvordan fungerer den menneskelige bevissthet? Kunne dette nå forklares ved hjelp av studiet av nevroner og synapser i hjernen? John O'Keefe reflekterer omkring dette i artikkelen «Kant and the sea-horse: an essay in the neurophilosophy of space» (1993), en tekst som går lenger i retning filosofisk refleksjon enn det som er vanlig i nevrobiologien. ${ }^{\text {xiii }}$ Sjøhesten som tittelen viser til, er nettopp hippocampus, den høyst interessante delen av menneskets hjerne som har form av en sjøhest - derav det greske og latinske navnet.

I artikkelen viser O'Keefe hvilken tankegang som lå til grunn for teorien om stedceller i hippocampus. Hippocampus ligger dypt i hjernen og har en relativt enkel oppbygning, en 
slags opprinnelig korteks med en trelags struktur med identiske celler. Input til hippocampus kommer primært fra entorhinal korteks og septum. ${ }^{\text {xiv }}$ Det fins celler i ulike deler av hjernen som forholder seg til sted, tid og retning, men cellene i hippocampus avfyres ved endringer $\mathrm{i}$ det ytre rom; de er såkalt allosentriske. Derfor tok O'Keefe og Nadel utgangspunkt i nettopp disse cellene da de utviklet teorien om at hjernen tegner et kognitivt kart over omverdenen som anvendes når et dyr skal orientere seg i verden og lagre informasjon om mat, hindringer, andre aktører og bevegelsesruter. ${ }^{\mathrm{xv}}$

\section{Nevroner: impulsene som styrer bevissthet}

For å forstå rekkevidden av denne teorien, må vi se litt på hvordan nevrovitenskapen de siste tiårene har utvidet kunnskapen om hvordan hjernen fungerer. Hvordan mottar nervecellene inntrykk, prosesserer dem og sender dem videre til andre deler av hjernen? Hvordan kommuniseres kunnskapen til andre celler? Nevronene spiller en viktig rolle her. Et nevron er en celle i nervesystemet. Den består av en cellekjerne og lange tråder som kalles aksoner. ${ }^{\text {xi }}$ Nerveimpulsen går som et elektrisk signal fra cellekroppen ut i aksonet, som ender i en aksonterminal - der det frigjøres stoffer som kan påvirke neste nervecelle. Her kan typisk informasjon komme inn i nevronet $f \varnothing r$ den prosesseres i cellekroppen og sender ut signal som neste celle mottar gjennom dendritten. ${ }^{\text {xii }}$ En nervecelle mottar informasjon fra tusenvis av andre nerveceller der ute i dendrittene og tar en slags «demokratisk» beslutning om hvorvidt den skal sende en nerveimpuls ut i aksonet eller ikke. Prosesseringen er altså ganske forskjellig fra en datamaskin.

Men så kommer det interessante: selve signalet fra én celle til den neste. Aksonene kan være fra noen millimeter og helt opp til nesten en meter. Signalet går fra cellekjernen ut til enden av aksonet, men der er det stopp. Vi finner et lite tomrom, et gap, mellom aksonets sluttpunkt og dendritten. I avstanden mellom disse to oppstår det en spenning, en elektrisk spenning på mikronivå som utløses av kjemiske stoffer (diffusjon). Denne overgangen mellom to nerveceller er det som kalles synapsen. Det er typisk på dette stedet at legemidler og narkotiske stoffer virker. Det er altså her vi kan påvirke prosessen - signalet i aksonet lar seg ikke påvirke i noen særlig grad.

Signalet overføres fra den ene cellen til den andre i det lille mikrosekundet når spenningen utløses ved en kjemisk prosess og overføres til neste celle. Det er imidlertid et helt uoverskuelig nettverk av nerveceller i den menneskelige hjernen, opp mot 100 milliarder. Og hvert enkelt nevron kan ha mangfoldige synapseforbindelser. Det er altså flere forbindelser i den menneskelige hjerne enn det er stjerner i Melkeveien. Det kan virke overveldende, men som Kant sa: «To ting fyller meg med stadig ny og tiltagende undring og ærefrykt [...]: stjernehimmelen over meg og moralloven inni meg.» xviii Ifølge nevrobiologien er hjernen stedet der vi oppfatter begge deler - samt undring og ærefrykt.

\section{Stedceller, gridceller og hjernens GPS}


Cellenes struktur og utvikling oppdaget man i årene etter krigen, men det var først i 1971 at John O'Keefe identifiserte celler som var spesifikt forbundet med orientering i rommet, gjennom fors $\varnothing \mathrm{k}$ på rottenes hippocampus. Innenfor buret løp rottene i alle retninger. De hadde små elektroder festet til hjernecellene som registrerte hvordan cellene ble avfyrt på bestemte steder i rommet, og på den måten registrerte punkter som bidro til å etablere et

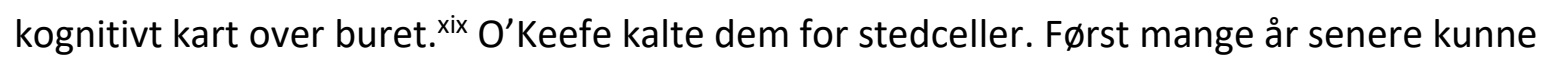
man påvise at også mennesker har slike stedceller.

Siden har man funnet andre typer celler som også forholder seg til rommet: Hoderetningsceller, fartsceller, grenseceller og grid- eller gitterceller. ${ }^{x x}$ Disse befinner seg ikke alle i hippocampus, men også i området rundt, entorhinal korteks. I løpet av en tredveårsperiode var det en rivende utvikling på feltet. Man oppdaget stadig nye celletyper som kom med viktig informasjon, og teorien gikk ut på at det var en stadig informasjonsstrøm mellom ulike typer celler som gikk oppover og nedover i systemet. På denne måten kunne rottene - og tilsvarende også flaggermus, aper og mennesker - lage seg et indre bilde av omverdenen og navigere i dette rommet. Man så derfor for seg et system som ikke bare lignet en GPS - altså koder for et sted - men som kunne knytte sted, tid og rom sammen til komplekse minner. Med andre ord: vår autobiografi, vår selvforståelse og identitet. Et selv.

Det tredimensjonale kartet i hippocampus viste seg å være litt upålitelig. Cellene kunne plutselig endre aktiviteten, altså stedet der de var aktive, hvis det skjedde noe uventet. Forskerne lurte derfor på om det kunne finnes et mer pålitelig kart utenfor hippocampus. I årene 2005-2006 var det så noen forskere i laben til Edvard og May-Britt Moser ved NTNU som gjorde fors $\varnothing \mathrm{k}$ med rotter der de registrerte aktivitet utenfor hippocampus, i midtre entorhinal korteks (MEC). Torkel Hafting og Marianne Fyhn tilhørte på den tiden laben til Moser og Moser og utførte forsøkene. På tvers av forventet resultat oppdaget de at disse cellene ble avfyrt i et bestemt mønster, etter en plan, så å si. ${ }^{\text {xxi }}$ De bidro til å kartlegge rommet gjennom trekanter, som igjen formet sekskanter, heksagoner. ${ }^{\text {xii }}$ Ved hjelp av dette rutenettet kunne faktisk rottene skape seg et kart for å navigere i rommet. Kartet kunne også utvides til større områder, men etter samme mønster. De antok at dette er en måte å kategorisere verden på som ligger i selve nervesystemet, og som har blitt bevart relativt stabilt opp gjennom seleksjonen.

Uttrykket «hjernens GPS» er omstridt - men ganske nyttig. xxiii Ettersom man kunne orientere seg tredimensjonalt, handlet det ikke bare om et kart lokalisert ved stedceller, men et tredimensjonalt orienteringsgitter der man selv kunne posisjonere seg, altså gridceller - et Grid Positioning System, om man vil. Metaforen er ganske treffende på en modell som hjelper oss å forstå hvordan hjernen fungerer når vi orienterer oss i verden: Ved hjelp av tredimensjonale kart kan vi gjenfinne vår posisjon, utvide med nye heksagoner etter samme mønster, bevege oss og samle informasjon.

\section{Syntetisk a priori: Kant og nevrovitenskapen}


For å se nærmere på de filosofiske konsekvensene av dette argumentet må vi vende tilbake til John O'Keefe. Han trekker det faktisk frem som et siste avgjørende argument i nobelforedraget fra 2014: Funnene i hjernens struktur mener han svarer til og derfor på et vis styrker Kants hypotese om rom og tid, slik den ble formulert i Kritik der reinen Vernunft i 1781. ${ }^{\text {xiv }}$ Ifølge Kant er ikke rommet noe vi kan ta for gitt i den ytre verden, altså noe som møter oss «der ute». Rommet formes tvert imot av fornuftens mulighet for å oppfatte og strukturere det. Rom og tid må være gitt oss som anskuelsesformer a priori, altså forut for erfaringen, hevder han, to modi som gjør det mulig for oss å oppfatte og strukturere den ytre virkeligheten. ${ }^{x x v}$ Uten disse anskuelsesformene er ikke den ytre virkeligheten tilgjengelig for oss overhodet. Vi kan ikke tenke eller forestille oss verden uten anskuelsesformene tid og rom. Men likevel, hevder Kant, er det altså ikke noe vi finner der ute, i verden. Det er noe som vi selv bringer med til verden og former inntrykkene gjennom. Erkjennelsesteoretisk er dette et ganske viktig poeng.

O'Keefe beskriver det som en diskusjon om grunnleggende erkjennelsesprinsipper der Kant står mot empiristene Hume og Berkeley. ${ }^{x x v i}$ Empiristene hevdet at erkjennelsen ikke kan ta noen ideer for gitt, med mindre de er strengt logiske. Utover det må vi kun stole på sansene våre og det de erkjenner i den ytre verden. Kant diskuterer dette argumentet og gir en delvis tilslutning, men peker på at også sanseerkjennelsen er usikker. Derfor må vi analysere alle våre inntrykk og spørre etter mulighetsbetingelsen for slike inntrykk overhodet. Da kommer han frem til at tid og rom er slike mulighetsbetingelser som ikke er gitt ved tingene selv, men ved fornuftens erkjennelse av dem. ${ }^{\text {xxvii }}$ Det kan beskrives som et slags nett, et fiskegarn eller koordinatsystem, som vi kaster ut over verden - og det vi fanger opp gjennom dette nettet, er virkeligheten slik vi er i stand til å oppfatte den. Andre tråder i Kants erkjennelsesteoretiske nett er årsakskategorien og de andre elleve kategoriene som vi bruker til å strukturere inntrykk, erfaringer og tanker gjennom, og som gjør det mulig for oss å oppfatte verden slik vi gjør det.

Hvordan kan vi forestille oss dette, og hva har det med hjerneforskning å gjøre?

Det kan være nyttig å ta utgangspunkt i nettet, koordinatsystemet, som metafor. Uttrykket grid cells betyr nettopp gitter- eller nettceller. Gridcellene fungerer altså som et slikt nett eller skaper et slikt nett inne i vår bevissthet som strukturerer hjernens oppfattelse av verden. Vi kan ikke endre på dette, vi kan ikke komme bakenfor nevronene og gjøre det annerledes (vi kunne i høyden forsøke å manipulere dem), men nettopp derfor er det interessant å se hvordan hjerneforskningen i utviklingen av hypotesen har basert seg på Kant, slik John O'Keefe argumenterer for i artikkelen fra 1993. Og dette skriver han tolv år før Hafting og Fyhn gjør den banebrytende oppdagelsen av gridcellene sammen med Moser og Moser, som gir et mer fullstendig bilde av hvordan nevronene strukturerer vår oppfattelse av verden.

O’Keefe mener altså at nevrovitenskapen styrker Kants hypotese snarere enn Berkeleys empirisme og vår tids naturalisme. Det er nemlig lite som tyder på at vi ville være i stand til å 
orientere oss i rommet dersom ikke hjernen strukturerte det for oss. Og nevronene i hippocampus ser ut til å strukturere rommet etter prinsippene for euklidsk geometri - som Kant holdt for å være den eneste mulige. Etter Kant har riktignok matematikere og fysikere som Gauss og Einstein vist at rommet kan struktureres annerledes, på måter som bryter med Euklids prinsipper. Likevel er det $\mathrm{i}$ henhold til disse prinsippene at dyrenes hjerne strukturerer inntrykkene når vi studerer dem i laboratoriet. O'Keefe ser dette som ytterligere et tegn på at Kants hovedteori er riktig. Når hjernen forholder seg til en euklidsk forståelse av rommet med rette linjer og tre dimensjoner, kan dette best forklares ut fra evolusjonen, argumenterer han. ${ }^{x x v i i i}$ Det har gitt en fordel i seleksjonen dersom man var $\mathrm{i}$ stand til å orientere seg i rommet og finne de korteste vektorlinjene tilbake til mat, identifisere farer og vende tilbake til flokken. ${ }^{\text {xxix }}$

Det interessante med hypotesen er at den er teoridrevet. O'Keefe er ikke bare nevrobiolog, han har også studert klassiske tekster og filosofi, og Kants perspektiv blir en modell for hans egen hjerneforskning. Men samtidig er det et problem som O’Keefe ikke har tenkt så grundig igjennom, nemlig at hans teori strengt tatt også undergraver hele Kants teoretiske filosofi. For O'Keefe er det riktignok åpenbart at de filosofiske spørsmålene ikke lar seg eliminere ved en reduksjon av metodene. Men for Kant er tid og rom gitt ved fornuften, forut for erfaringen. I henhold til O'Keefe er den utviklet $i$ hjernen gjennom evolusjonen. Det er to ganske forskjellige synspunkter, selv om de ikke nødvendigvis er helt uforenlige. Virkelig interessant blir det hvis man begynner å stille spørsmål om forholdet mellom hjernen som biologisk prosess og fornuften som uttrykk for (menneskers ellers dyrs) bevissthet.

\section{Nevrofilosofi og eliminativ materialisme}

Patricia S. Churchlands bok Neurophilosophy (1986) markerte et vannskille i den filosofiske tilnærmingen til nevrovitenskapen. Mens philosophy of neuroscience diskuterer filosofiske grunnlagsproblemer i nevrovitenskap (slik O’Keefe gjør med referanse til Kant), anvender nevrofilosofien den nye innsikten om hjernen og nevronene på tradisjonelle filosofiske problemer. Churchland understreker at nevrovitenskapen er i ferd med å endre vår forståelse av virkeligheten fundamentalt, og dermed også betingelsene for filosofisk erkjennelse. Patricia Churchland kommer fra den analytiske bevissthetsfilosofien (philosophy of mind), men mener at den nye innsikten i hvordan hjernen fungerer, åpner helt nye muligheter for å forstå hvordan vår bevissthet og hukommelse er basert på nervesignaler bundet sammen i hjernen. Nervesignalene styrer kroppens bevegelser og tanker, registrerer sanseinntrykk og prosesserer disse til en helhetlig oppfattelse av verden der mennesket er både mottagende og handlende. I likhet med sin mann, nevrofilosofen Paul M. Churchland, er Patricia Churchland talskvinne for en såkalt eliminativ materialisme.

«Eliminativ materialisme» innebærer at alle forklaringer på bevissthet, persepsjon og refleksjon, ifølge Churchland og Churchland, har en materiell basis og i prinsippet kan reduseres til materielle årsaker og virkninger, altså neuroscience. ${ }^{\mathrm{xx}}$ Denne posisjonen har også betydning for hvordan man forklarer hendelser kausalt: Selv om man godt kan tenke 
seg at mentale representasjoner (tanker, følelser osv.) korresponderer med fysiske nervesignaler, vil det alltid være sistnevnte som er årsak til førstnevnte, ikke motsatt. Uttrykt med andre ord: For en eliminativ materialist er vi vår hjerne, ikke vår sjel (eller vårt hjerte, for den saks skyld). Alle faktorer, handlinger osv. som vi forklarer ut fra vår bevissthet, er $\mathrm{i}$ siste instans en illusjon - selv om også illusjonen kan være en nyttig forklaringsmodell i mangel på innsikt i hvordan nevroner fungerer. Nevrofilosofien har gjort reduksjonisme til sitt program. ${ }^{x x x i}$ I tillegg forutsetter man en såkalt ko-evolusjonær forskningsideologi, dvs. at psykologi og nevrovitenskap kan lære om menneskehjernen ved å studere enklere organismer, som for eksempel aplysia og drosophila. I selve forskningsideologien er det en implisitt reduksjonisme som neppe kommer helt til rette med spørsmålet om menneskets bevissthet eller hvordan vi som mennesker oppfatter tid og rom. xxxii Paul Churchland tar også eksplisitt til orde for en slik reduksjonisme. Han mener at alle våre tanker og overbevisninger vil bli eliminert så snart vi er i stand til å identifisere de nevrologiske prosessene i korteks mer fullstendig - like overflødige som eter og hekser i gammel tid. ${ }^{x x x i i i}$

Paul Churchland har gitt viktige teoretiske bidrag til nevrofilosofien ved å utvikle tanken om hjernen som en slags computer, som tar inn informasjon og «prosesserer» den videre. Det er neppe helt tilfeldig hvilke metaforer som dominerer i denne vitenskapsteorien. Når Paul Churchland skriver om the computational brain, forutsetter han at hjernen fungerer som en avansert computer, og at kunstig intelligens i prinsippet bare etterligner denne strukturen. Han supplerer dette med en teori om nevronene og deres signaler forstått som vektorer og nevronenes overraskende evne til å videreutvikle seg gjennom plastisitet. Noe tilsvarende gjelder Daniel Dennetts nevrofilosofi. Hjernen er for Dennett en fleksibel computer som er plastisk, og som derfor hele tiden kan utvikle seg videre, reparere feil og bygge ut nye nervebaner. ${ }^{\text {xxiv }}$

Daniel Dennett har i likhet med Churchland og Churchland argumentert for at all filosofi må være naturalistisk og empiristisk for å unngå å formidle nonsens. Han hevder det er mulig å forklare bevissthet gjennom hjernens funksjoner, og at moral og religion kan forklares gjennom en kombinasjon av evolusjonsteori og nevrobiologi. ${ }^{x \times v}$ lkke alle nevrofilosofer er like reduksjonistiske som Dennett, men de hevder med en viss tyngde at det er nettopp reduksjonismen som legitimerer hjerneforskningen, som gjør det mulig å forklare psykologi, biologi og medisin ut fra kjemiske og biologiske prosesser i hjernen.

Ikke alle nevrobiologer går så langt fordi de innser biologiens begrensning. Men Squire og Kandel argumenterer for at det er en slik reduksjonisme som har muliggjort nevrobiologiens suksess, ved at man tar utgangspunkt i behaviorismen, som vil gi en vitenskapelig forklaring på atferd, og deretter forklarer atferd ved hjelp av prosesser i hjernen, som igjen kan forklares ved hjelp av nevroner, synapser og kjemiske prosesser. ${ }^{\text {xxvi }}$ Fra å ha vært en deskriptiv vitenskap blir biologien en eksperimentell vitenskap som gir eksakt kunnskap både om hjernens funksjoner og om verden rundt oss. Som eksempler på dens suksess nevner Kandel at psykologien nå kan forbedres betraktelig og til dels erstattes av effektive 
legemidler som gjør kjemiske forandringer i hjernen. Endelig er det mulig å gi presise diagnoser og effektivt hjelpe den som er psykisk syk, hevder han. ${ }^{x x x v i i}$

\section{Nevrofenomenologi og epigenese}

Selv om reduksjonismen er en metodisk forutsetning for nevrovitenskapen, er det vanskelig å se hvorfor det skulle være en nødvendig konsekvens av den. Det fremholdes som et vitenskapelig ideal, men viser seg med Churchlands eget uttrykk å være en forskningsideologi. Metodepluralisme fremheves gjerne som et ideal innenfor vitenskapsfilosofien for å etablere ulike perspektiver på et empirisk materiale. Den analytiske nevrofilosofien domineres imidlertid av en slags hybris på hjernens og livsvitenskapens vegne. Derfor representerer fenomenologien et viktig kritisk korrektiv til den naturalistiske nevrofilosofien. Den moderne fenomenologiens grunnlegger Edmund Husserl advarte i foredraget Die Krisis der europäischen Wissenschaften (1936) mot det han kalte en matematisering av verden. ${ }^{\text {xxxvii }}$ Husserl var selv matematiker, men mente at matematikken hadde gått fra å være en hjelpevitenskap til å dominere hele det moderne verdensbildet.

Husserl kritiserer sin tids naturvitenskap for kun å kaste et koordinatsystem ut over verden, og bare la det som kan måles og etterprøves eksperimentelt, fanges opp av forklaringene. Alt det andre faller bort. ${ }^{\text {xxxix }}$ Den kan på et vis forklare alt, men det er også alt den kan forklare. Selve utgangspunktet for denne tenkningen problematiseres av Husserl. Han mener at en først må foreta en filosofisk analyse av de transcendentale betingelsene for erkjennelsen før vi kan regne resultatene som troverdige. Det er ikke virkeligheten selv vi erkjenner i laboratoriet eller mikroskopet, det er en helt bestemt fortolkning av den, på mange måter en naiv og reduksjonistisk fortolkning. ${ }^{\mathrm{xl}}$

Husserls alternativ til reduksjonismen er å ta utgangspunkt i menneskets livsverden, der erkjennelse og bevissthet formes av inntrykk og fenomener vi ikke har kontroll over. Enhver gjenstand, ethvert fenomen, er underlagt en annerledeshet som unndrar seg vår forklaring. xli Husserl er på mange måter antirealist, ikke fordi han ikke tar den ytre virkelighet for gitt, som natur, men fordi nettopp det naturlige kan erfares på så mange ulike måter. Og fenomener som bevissthet, hukommelse, forventning og selvet er også bestemt av andre aspekter enn de matematiske koordinatene - eller i vårt tilfelle: nevronene. Det er riktig nok at vi ikke kommer utenom fysikkens lover, heller ikke utenom nevronene, men nevronene som forklaring på fenomener og sammenhenger gir oss ikke noen genuin forståelse av disse fenomenene. ${ }^{\text {lii }}$ Skal vi forstå bevissthet og hukommelse, og den menneskelige oppfattelse av tid og rom, må vi anerkjenne at vi transcenderer den eliminative materialismen. Det underlige er at selv den eliminative materialismen forutsetter en slik transcendens, men ikke vil vedstå seg den eller anerkjenne den. Uten et slikt nærvær, en slik transcendens knyttet til bevissthet, er det vanskelig å forestille seg hvordan vi skulle kunne organisere tiden ut fra en fortid, en fremtid og en nærværende tid. Det er vanskelig å forestille seg hvordan vi skulle erkjenne eller gjenkjenne oss selv og andre som mennesker. Også religionsfilosofisk handler 
dette om erfaringer som overskrider de rent materielle, selv om vi skulle forutsette at overskridelsen finner sted $i$ og gjennom nevronene. Nevronene muliggjør erfaring av transcendens - men uten en slik overskridelse av det materielle ville vi ikke kunne erkjenne og reflektere over nevronenes persepsjon.

I en fenomenologisk sammenheng kan dette karakteriseres som en naturlig, refleksiv realisme. Dan Zahavi innrømmer at Husserl ikke er en vitenskapelig realist, men han mener at nevrovitenskapen i filosofisk sammenheng er en blindvei fordi den avstår fra å reflektere over sin egen erkjennelse. Husserl representerer derimot det Zahavi vil kalle en refleksiv og naturlig realisme:

This is also why Husserl would write that his 'transcendental idealism' contains natural realism within itself (Hua 9/254), since it is an explication of the sense that the world has for all of us 'prior to any philosophizing' (Hua 1/36). Indeed there is nothing wrong with the natural attitude and with our natural realism; what Husserl takes exception to is the philosophical absolutizing that we find in metaphysical realism (Hua 3/120). ${ }^{x \text { liii }}$

I stedet for å konstruere en absolutt virkelighetsforståelse vil Zahavi prøve fenomenologiske beskrivelser opp mot nevrovitenskapen i en anerkjennelse av den grunnleggende forskjellen mellom disiplinene. Det er den kognitive og fenomenologiske differensen og spenningen mellom disse helt ulike erkjennelsesmodellene som gjør tankeutvekslingen interessant og provoserer frem ny erkjennelse. Dette er etter min vurdering et helt avgjørende premiss for utviklingen av en nevro-fenomenologi, som baserer seg på det vi kan kalle en kritisk realisme

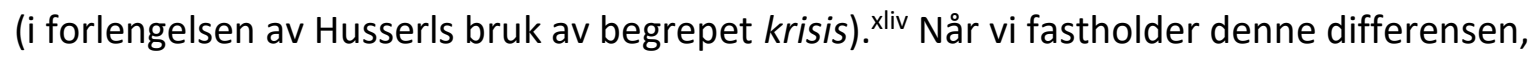
ser vi at nevrobiologien kan forklare tid og rom på et bestemt nivå, ut fra orientering $\mathrm{i}$ rommet, gjenkjennelse og organisering av koordinater i tredimensjonale grids. Men erfaringene overskrider disse begrensningene. Ta et så grunnleggende fenomen som tid, som Augustin deler inn i fortid og fremtid. Ifølge Augustin er det bevisstheten som skiller mellom dem, som i hukommelsen (memoria) fastholder fortiden, og i forventningen (expectatio) relaterer til fremtiden. Hvordan definere minne og glemsel, håp og skuffelse, nærvær, elastisitet, plastisitet og resiliens uten denne evnen til å transcendere den biologisk gitte materien, til tross for at det skjer i og gjennom det materielle, i nevronene og gjennom synapsene? Her kan vi si at forholdet mellom nevroner og transcendens fortettes: Transcendensen kan spores helt inn i nevronene, men forutsetter samtidig en slik overskridelse for å lokalisere den til nevronene. Når vi jevnfører begrepet 'bevissthet' med 'ånd', blir det tydelig at også religionsfilosofien kan reformuleres ut fra en slik nevronal bestemmelse av transcendens. Her kan vi lokalisere erfaringer med bønn, med meditasjon, med et guddommelig nærvær, selv om det selvsagt ikke kan forstås som en tilstrekkelig forklaring på begrepet 'Gud'. En slik reduksjonisme vil bare bidra til å utelukke eller bortforklare erfaringer vi oppfatter som meningsfulle, overskridende eller omkalfatrende, enten som enkeltpersoner eller som del av et fellesskap. 
Husserls fenomenologiske analyse av (indre og ytre) tidsbevissthet er mer subtil enn det vi finner hos Augustin og sprenger rammene for denne artikkelen. ${ }^{x l v}$ Men premisset for hans kritiske realisme er fenomenologisk - dvs. at det vi oppfatter og forstår i studiet av nevroner og synapser, slett ikke er virkeligheten selv, men et helt bestemt og relativt snevert perspektiv på virkeligheten: et språk, et koordinatsystem. Det gir en presis beskrivelse av bestemte funksjoner og overganger som åpner helt nye perspektiver for filosofisk erkjennelse - men det vil uvegerlig overse eller misforstå premissene for sin egen erkjennelse. Interessant nok er det en nevro-fenomenologi tilsvarende den Zahavi beskriver som svarer best til John O'Keefes refleksjon over nevrovitenskapens betydning for oppfattelsen av rommet. Zahavis forslag om å la nevrovitenskapens observasjoner utfordre, bekrefte og eventuelt overprøve fenomenologiens hypoteser, etablerer imidlertid et annet paradigme for å forstå forholdet mellom bevissthet, persepsjon, nevroner og synapser: nevrofenomenologien. ${ }^{\text {lvi }}$

Den franske filosofen Cathérine Malabou er blant dem som har tatt opp utfordringen fra nevrovitenskapen fra et mer fenomenologisk og politisk perspektiv, i første rekke gjennom boken What Should We Do with Our Brain? xlvii Malabou griper fatt i begrepet plastisitet som er blitt sentralt i beskrivelsen av hjernens utvikling og fleksibilitet, men argumenterer samtidig for at dette er et politisk begrep som svarer til en bestemt $\varnothing$ konomisk og nyliberalistisk ideologi som preget verden tidlig på 2000-tallet. xlviii Hun påpeker at nevrofilosofene ikke engang er oppmerksomme på denne koblingen, som hun mener i stor grad kan forklare hvorfor nevrovitenskapen på kort tid har fått så stor oppmerksomhet og hegemonisk status for virkelighetsforståelsen i store deler av verden. Andre viktige innvendinger mot nevrovitenskapens hegemoni er mangelen på kritisk diskusjon rundt de etiske og epistemologiske konsekvensene av dens reduksjonisme. Den fører ifølge Malabou til en blind tro på kognitive forklaringer av sykdom og svakhet, en sykeliggjøring i form av en psykologisering av samfunnet, der barn defineres som hyperaktive og voksne som depressive - og begge kategorier skal behandles med medikamenter. Dette åpner for et gigantisk marked innen psykofarmaka-kapitalismen som innebærer en kjemisk manipulering av hjernen innen store segmenter av befolkningen. ${ }^{x l i x}$

Malabou er sterkt kritisk til denne utviklingen, samtidig som hun ser at nevrovitenskapen reiser interessante filosofiske problemstillinger. Disse kan imidlertid først formuleres konstruktivt når begreper som 'plastisitet' og 'fleksibilitet', men også 'bevissthet' og 'nevroselv', kan drøftes kritisk fra ulike perspektiver, inkludert spørsmål om etikk og epistemologi, makt og autonomi. Malabou understreker at dette må være en dialektisk tilnærming som tar høyde for ny innsikt i nevrobiologien, men samtidig relaterer den til fenomenene og deres etiske og politiske aspekter, slik Hegel gjorde i sin analyse av begrepet plastisitet. ' Dette svarer til hva vi her har kalt en kritisk og refleksiv realisme.

I sin siste bok, Before Tomorrow, går Malabou dypere inn i de vitenskapsteoretiske problemene som nevrovitenskapen reiser. Kant forutsetter tid og rom som a priori 
betingelser for erkjennelsen i likhet med andre transcendentale betingelser som kausalitet. Men hvordan skal dette a priori forstås antropologisk - som en slags medfødt evne eller en struktur som er gitt i menneskets fornuft? Kant selv unngår å diskutere problemstillingen, men ser den ikke uansett ganske annerledes ut et par hundre år senere? Forskningen på hvordan hjernecellene legger betingelser for vår oppfattelse av tid og rom, gjør det vanskelig å fastholde dette som a priori-kategorier, altså transcendentale forutsetninger gitt ved fornuften selv.

Dette siste trekker Malabou frem som nevrobiologiens store utfordring til filosofien, men hun er likevel ikke villig til å oppgi diskusjonen om premissene. Til denne diskusjonen mener hun at det fortsatt ikke fins noen bedre premissleverandør enn nettopp Kant, men det forutsetter at man leser Kant mot Kant, slik Heidegger gjorde i sine Kant-forelesninger. Dermed tematiseres igjen tiden som filosofisk problem, slik den gjorde hos den tidlige Heidegger. Det begrep Malabou griper fatt i, er uttrykket «epigenese», som Kant nevner i $\S 27$ av Kritik der reinen Vernunft. li Dette er interessant nok et begrep som også spiller en viktig rolle i hjerneforskningen, koblet opp mot evolusjonsteori. Poenget er at de ulike nevronene og synapsene i hjernen utvikler seg gradvis, epigenetisk, og som en respons på impulser utenfra. Dette får igjen betydning for hvordan man oppfatter tid og rom, kausalitet og bevissthet. Det er således illusorisk å forutsette en «ren» fornuft uavhengig av de biologiske betingelsene for bevissthet i hjernen, men ifølge Malabou er det like illusorisk å tenke seg at bevissthet er et rent produkt av nevronal aktivitet. ${ }^{\text {lii }}$

Her vil jeg ta refleksjonen et steg videre, lest opp mot diskusjonen omkring tids- og gridceller. Spørsmålet om tid og synapsenes utvikling blir da nemlig ikke bare et dilemma knyttet til materielle betingelser for hjerneaktivitet, men til spørsmålet om hva og hvem vi er, i tidslig forstand, og hvem vi blir, hvordan vi er i stand til å fastholde minner $\mathrm{i}$ hukommelsen, og hvordan vi glemmer og sporene slettes ut. .iii Det er altså ikke bare et spørsmål om materie som utelukker en sjelelig eller åndelig forklaring på bevissthet (eliminativ materialisme), men om hvordan materien kan sies å romme det åndelige, dels ved å formes av refleksjoner og sanseinntrykk, men også ved selv å utfolde seg, forestille seg en virkelighet, tenke fremover og tilbake i tid - slik Augustin skisserte problemet $\mathrm{i}$ Confessiones XI. Malabou beskriver en slik eksistensiell fortolkning av tiden med henvisning til Ricoeur:

Genesis always bring the new back to the old, while epigenesis marks the current valency of the meeting point between the old and the new, the space where they reciprocally interfere and transform one another - the embryo of a specific rationality. [...] Teleology is a prospecting tension towards the future which recitifies after the fact the primitive or "archaic" tensions that made it possible. liv

Riktignok er det vanskelig å forestille seg 'sjel', 'ånd' og 'fornuft' uten en kroppslig, ja, nevronal, basis, men er det ikke omtrent like vanskelig å forestille seg en rent materialistisk kausalsammenheng mellom synapsene som avfyres, og den forestillingsverden som 
kjennetegner den menneskelige bevissthet? Om ånden kan sies å være inkarnert, må hjernen kunne sies å åpne opp for en forestillingsverden av tid og rom. For Kant er det ved yttergrensen av en slik forestillingsverden at vi kan forestille oss Gud som opphav - og han postulerer en slik forutsetning - men i dette paradigmet er det innenfor strukturene at denne overskridelsen finner sted. Transcendens er altså ikke primært et spørsmål om «innenfor» og "utenfor» verden, men om en overskridelse av materialismen, som igjen setter spor i nevronenes reaksjoner. ${ }^{\text {Iv }}$ Hvis Guds transcendens skal relateres til livsvitenskapen, handler det nettopp om nærværets overskridelse av biologien, hvilket kjennetegner det vi fortsatt definerer som 'liv', enten i bevisst intensjonal forstand eller passivt mottagende erfaring (Widerfahrnis), som ved en skapelse ex nihilo.

En slik kritisk tankeutveksling som analyserer resultatene fra hjerneforskningen i lys av fenomenologien - og motsatt - kan vise seg å bli viktig ikke bare for livsvitenskapens del, men også for filosofi og teologi. Det kan gi oss en relativt presis og realistisk forståelse av tid og rom, situert i en kroppslig erfaring og innenfor den menneskelige mulighetsbetingelse for erfaring og bevissthet, som er gitt ved livet og avgrenset ved døden.

\section{Livsvitenskap og teologi: $d \varnothing d$ vinkel og differens}

Hjerneforskere og nevrofilosofer har ikke bare beskjeftiget seg med studiet av nevroner og synapser de siste årene. De har også beveget seg inn på teologiens område og diskutert muligheten av Guds eksistens i lys av nevrovitenskapen og ulike forståelser av religiøsitet ut fra et bestemt begrep om religiøs erfaring, slik den kan registreres ved hjerneaktivitet og gjentas eksperimentelt i laboratoriet. Daniel Dennett er nok mest berømt for sin bok Breaking the Spell: Religion as Natural Phenomenon (2006), som vil forklare religion ut fra nevrobiologi, teorien om memer og darwinistisk evolusjonsteori. Det er ikke vanskelig å si seg enig i Dennetts første poeng, nemlig at «forbannelsen» må brytes ved at religion også kan studeres som naturlig fenomen. Men dette er strengt tatt ikke et nytt poeng - religion har vært studert som historisk, antropologisk, politisk, psykologisk, sosiologisk og «naturlig» fenomen de siste 150 år, og her fins det neppe særlig sterke begrensninger. Problemet med Dennetts tilnærming er at han diskuterer spørsmålet om religion med utgangspunkt $i$ at religion er nonsens som skal forklares nevrobiologisk. Det blir det verken god nevrovitenskap eller særlig interessante synspunkter på religion eller teologi ut av.

De siste årene har det vært en markant økning innenfor såkalt kognitiv religionsvitenskap (CSR), som analyserer ulike religiøse erfaringer gjennom deskriptive og eksperimentelle studier, men som deler tre viktige metodologiske premisser: naturalisme, evolusjonsteori og utviklingspsykologi. 'vi 'Religion' reduseres da til religiøse erfaringer, i den grad disse kan registreres som kognitive impulser i hjernen, som så produserer bestemte forestillinger om liv og $d \varnothing d$, bevissthet, overnaturlige vesener og guder. Men hva er det som her kalles 'religion' eller 'religiøs erfaring'?lvii De eksperimentelle studiene innenfor CSR forutsetter en ontologisk, epistemologisk og metodologisk reduksjonisme som i prinsippet utelukker teologiske og religionsfilosofiske problemstillinger der sannhetsspørsmålet diskuteres åpent 
ut fra ulike erkjennelsesteoretiske premisser. Dette svekker det kritiske og vitenskapelige potensialet for det nevrobiologiske studiet av religion ettersom det forblir tekniske registreringer av et kunnskapsfelt der forskerne ikke engang forstår de mest grunnleggende premissene. Symptomatisk for denne forskningslitteraturen er dessuten at den fors $\varnothing$ ker å etablere de antatt «religiøse» erfaringene som et religionssubstitutt, snarere enn å interessere seg for religionenes og teologiens samfunns- og vitenskapsteoretiske relevans. ${ }^{\text {|viii }}$

Cathérine Malabous bøker kaster et interessant lys over den diskursen som så langt har etablert seg som hegemonisk innenfor analytisk nevrofilosofi. Den eliminative materialismen representerer en $d \emptyset d v i n k e l$ eller blindsone for de problemstillinger som ikke reises når alle forklaringer reduseres til en diskusjon omkring nevroner og synapser, dvs. hvordan disse lagrer og prosesserer informasjon, og dermed legger premisser for hukommelse, mentale tilstander, sosiale relasjoner og handling. Jeg vil avslutningsvis peke på tre sider ved samfunnet der en slik reduksjonisme fremstår som både naiv og lite troverdig:

(i) det politiske aspektet, der nevrovitenskapen skjuler en bestemt antropologi som handler om kravet til plastisitet, å være fleksibel og tilpasse seg endring, slik at hjernen kan fungere optimalt innenfor de nye kravene til en globalisert $\varnothing$ konomi og arbeidsmarked;

(ii) det psykologiske eller psykiatriske aspektet, der etablerte hjerneforskere som Kandel og Squire ser utviklingen av kjemiske stoffer som virkelig kan helbrede mennesker som en av de viktigste fruktene av nevrobiologien. Ved kjemisk å endre strukturen i synapsene mener de å kunne helbrede deprimerte og psykisk syke. Et resultat av denne formen for forskningsideologi ser vi i dag i form av det største misbruk av medisiner i menneskehetens historie, drevet av sterke $\emptyset$ konomiske interesser innen psykofarmakaindustrien. Medisinene endrer den kjemiske og biologiske strukturen i hjernen for godt - med uoverskuelige konsekvenser. På samfunnsnivå ser vi sykeliggjøring i stor skala der unge og eldre diagnostiseres med depresjoner, mens barn ned i fem-seks års alder får diagnoser som ADHD og medisineres med ritalin, adderall og tilsvarende legemidler. lix $^{-}$

(iii) det religiøse aspektet, knyttet til CSR og religionskritikk. På dette feltet bidrar nevrofilosofien primært gjennom en ideologisk reduksjonisme av religiøse erfaringer og teologi til et spørsmål om evolusjon og nevronal aktivitet, mens religionsfilosofiens kritiske potensial i forhold til scientisme og darwinisme avvises som uvitenskapelig. Det er strengt tatt en svak vitenskapsteori som ligger til grunn for dette, som faktisk svekker troverdigheten til nevro- og livsvitenskapen mer generelt.

Samlet sett fremstår likevel det åpenbare skismaet mellom nevrovitenskapen og andre vitenskapelige disipliner som vanskelig å forklare. Nevrobiologen Per Brodal har nylig pekt på at hjerneforskningen overselges med hensyn til dens sosiale og medisinske implikasjoner og 
hevdet at vi står overfor en imperialistisk nevrokultur både i akademia og i samfunnet for $\emptyset$ vrig. ${ }^{\mid x}$ Dette er neppe særlig heldig med hensyn til de politiske, sosiale og psykologiske konsekvensene, men det er heller ikke gunstig for nevrovitenskapen, da dens troverdighet svekkes. For egen del har jeg store forventninger til den forskning som skjer innen livsvitenskapen og kanskje særlig nevrobiologien, men når fortolkningen av resultater og betydning er så svak og så forskningsideologisk styrt som vi ser i dag, svekkes faktisk troverdigheten til hele feltet. For å komme ut av denne dødvinkelen er brytningen mot tradisjonell psykologi, sosiologi, filosofi og teologi helt avgjørende for nevrovitenskapen selv - og i livsvitenskapens interesse.

Nettopp på dette punktet er det nevrofenomenologien blir interessant fordi den fastholder differensen mellom disiplinene, men samtidig får en filosof som Malabou til å reise spørsmålet om premissene for å reflektere over tid og rom på nytt, slik disse oppfattes gjennom nevronene. For teologi og kanskje særlig religionsfilosofi er dette en interessant problemstilling fordi den også problematiserer opplysningstidens gudsbegrep og definisjonen av en absolutt transcendens mellom det dennesidige (erfaringen) og det hinsidige (Gud). Denne absolutte grensen for erfaringen og inndelingen av ulike rom fremstår som uholdbar og på mange måter irrelevant når vi studerer inntrykk og oppfatning av tid og rom gjennom nevroner og synapser. Med den aktuelle problematiseringen av forholdet mellom tid og tidsoppfattelse, rom og romlighet, ånd og kropp, kommer også spørsmålet om premisser inn på et mer grunnleggende plan. Opplysningstidens problematisering av gudsbegrepet er forlatt. Gud som den absolutte makt «utenfor» verden, avgrenset fra enhver befatning med fenomenene, er og forblir irrelevant. Det gudsbegrepet som derimot gjør seg gjeldende, er det inkarnerte, det åndelig-kroppslige og det som avdekkes som premisser for liv og bevissthet i overgangen mellom mulighet og nødvendighet.

Filosofiens og teologiens viktigste oppgave er kanskje først og fremst å skape vanskeligheter, å stille vanskelige spørsmål og problematisere de kortslutningene som vi ser at nevrovitenskapen lett gjør seg skyldig i. John O'Keefe representerer et unntak fra tendensen til reduksjonisme. Han avviser at nevrovitenskapen løser problemer som filosofien har reflektert over siden antikken, slik som tid og rom. Tvert imot, den gir problemet enda en omdreining, samtidig som de tradisjonelle filosofiske problemene dukker opp på nye måter innenfor horisonten av nevrovitenskapen. Det er først når den også aksepterer at den må stille disse filosofiske spørsmålene, at nevrovitenskapen kan vinne frem til ny erkjennelse som sprenger rammene for rene pusleoppgaver, som Thomas Kuhn kalte dem.

Tilsvarende gjelder for psykiatrien, for biopolitikken, for det teologiske spørsmålet etter Gud. Skal vi tro Edmund Husserl, er ikke dette spørsmål som lar seg løse ved en metode, følgelig heller ikke ved nevrovitenskapens eksperimenter. Tvert imot er fortvilelsen, den relasjonelle fremmedgjøringen og den allosentriske troen på Gud (som alteritetserfaring) eksempler på 
problemstillinger som forstyrrer metoden, unndrar seg forenklende forklaringer og åpenbarer deres svakheter og begrensninger. Noe tilsvarende gjelder her.

Det er først når vi tar erfaringen og fenomenet på alvor, slik det oppleves i vår livsverden, at vi blir i stand til å nærme oss en forståelse - og ikke bare en forklaring - av bevissthet, av tid og rom. Men ved sin reduktive forklaring åpner livsvitenskapen likevel for helt nye perspektiver på religiøs erkjennelse samt en religionsfilosofisk problematisering av nevronenes hegemoni - innenfra. Differensen mellom nevroner som avfyres og erfaring kan synes ubetydelig, men så snart den er identifisert, kan den bli avgjørende for det liv som vi inntil nå har identifisert som menneskelig. Analysen av nevronene forutsetter en overskridelse, en transcendens, men en transcendens som livsvitenskapen selv ikke kan gjøre rede for. Denne transcendensen må filosofi og teologi få anledning til å utforske som fenomen, et fenomen som skjuler seg for det eksperimentelle blikket i laboratoriet. Også dette er uttrykk for en livsvitenskap. Kanskje er det først ved å vende tilbake til differensen mellom liv og død, fenomenologisk forstått, at også livsvitenskapen kan gjenoppdage og vedkjenne seg sitt opphav, sitt innhold og sin grunn. 
' Se Eric R. Kandel \& Larry R. Squire, «Neuroscience: Breaking down scientific barriers to the study of brain and mind", Science 2000; 290: 1113-20. https://doi.org/10.1126/science.290.5494.1113

ii Se Patricia S. Churchland, Neurophilosophy (Cambridge, MA: MIT Press, 1989); Paul M. Churchland, The Engine of Reason, the Seat of the Soul (Cambridge, MA: MIT Press, 1995); Daniel Dennett, Consciousness Explained (Boston: Little, Brown \& co, 1991).

iii Se Thomas Nagel, Mind and Cosmos (Oxford: Oxford University Press, 2012) og David Chalmers, «Facing up to the Problem of Consciousness". Journal of Consciousness Studies 2 (1995): 5-22.

iv Searle, John R., The Mystery of Consciousness (New York: New York Review of Books, 1990), 95-131.

$\checkmark$ 'Dan Zahavi, Husserl's Legacy (Oxford: Oxford University Press, 2017); Shaun Gallagher, Enactivist Interventions: Rethinking the Mind (Oxford: Oxford University Press, 2017).

vi Cathérine Malabou, Before Tomorrow, overs. C. Shread (Cambridge: Polity, 2016), 1-14.

vii Augustin, Confessions, overs. W. Watts, 2. Bind (Cambridge, MA: Harvard University Press, 1988), 238-9.

viii En god sammenfatning av forskningen på dette feltet de siste førti årene er nylig publisert i Nature av nettopp Moser og Moser: Edvard I. Moser, May-Britt Moser \& Brian McNaughton, «Spatial representation in the hippocampal foramation: a history», Nature Neuroscience 20 (2017): 1448-1464.

https://doi.org/10.1038/nn.4653

${ }^{i x}$ Se f.eks. Torkel Hafting, Marianne Fyhn, Sturla Molden, May-Britt Moser \& Edvard I. Moser, «Microstructure of a spatial map in the enthorinal cortex», Nature (2005) 436: 801-806. https://doi.org/10.1038/nature03721

${ }^{x}$ Se John O'Keefe \& J. Dostrovsky, «The hippocampus as a spatial map. Preliminary evidence from unit activity in the freely-moving rat», Brain Research (1971), 34:171-5. https://doi.org/10.1016/0006-8993(71)90358-1

${ }^{x i}$ Se Larry R. Squire og Eric R. Kandel, Memory: From Mind to Molecules. 2. utg. (Greenwood Village, CO:

Roberts, 2009).

xii Se Squire \& Kandel, Memory, 38-48.

xiii John O'Keefe, "Kant and the Sea-horse: an essay in the neurophilosophy of space», i Spatial representation: Problems in philosophy and psychology, red. av N. Eilan, R. A. McCarthy \& B. Brewer (Oxford: Blackwell, 1993), 43-64. Se også John O'Keefe \& Lynn Nadel, The Hippocampus as a Cognitive Map (Oxford: Oxford University Press, 1978), 18-24. Boken er fritt tilgjengelig under: http://cognitivemap.net/

xiv Se O'Keefe, «Kant and the Sea-horse», 51.

${ }^{x v}$ O'Keefe \& Nadel, Hippocampus.

xvi Se ulike varianter av nevroner med aksoner og dendritter i Squire \& Kandel, Memory, 32.

xvii Se fig. 1

xviii Immanuel Kant, Kritik der Praktischen Vernunft (Hamburg: Meiner, 2003), kap. 34.

xix Se O'Keefe \& Dostrovsky, «The hippocampus as a spatial map».

${ }^{x x}$ Jf. Kandel \& Squire, «Neuroscience».

xxi Se Hafting et al. 2005.

xxii Se fig. 2.

xxiii Se f.eks. diskusjonen i Hall R. Zucker \& Charan Ranganath, «Navigating the human hippocampus without a GPS», Hippocampus (2015), 25: 697-703. https://doi.org/10.1002/hipo.22447

xxiv Se nobelforedraget på: https://www.youtube.com/watch?v=POtXhEbvijg\&feature=youtu.be\&t=18m18s

${ }^{x \times v}$ Immanuel Kant, Kritik der reinen Vernunft (Stuttgart: Reclam, 1995), B 35-40.

xxvi O'Keefe \& Nadel, Hippocampus

xxvii Kant, Kritik der reinen Vernunft, B 38.

xxviii O'Keefe, "Kant and the Sea-horse», 58.

xxix O'Keefe, "Kant and the Sea-horse», 51-56.

xxx Se PM Churchland, "Eliminative materialism and the propositional attitudes". Journal of Philosophy 78

(1981): 67-90. https://doi.org/10.2307/2025900; Churchland, Neurophilosophy, 312.

xxi Jf. Churchland, Neurophilosophy, 356-62.

xxxii Se Churchland, Neurophilosophy, 374.

xxxiii Se Paul Churchland, Images of Science: Scientific Realism versus Constructive Empiricism (Chicago, IL: The University of Chicago Press, 1985); A Neurocomputational Perspective: The Nature of Mind and the Structure of Science (Cambridge, MA: MIT Press, 1989); Neurophilosophy at Work (Cambridge, MA: MIT Press, 2007). For mer kritiske perspektiver, se Maurice K.D. Schouten og Huibert Looren de Jong (eds.), The Matter of the Mind: Philosophical Essays on Psychology, Neuroscience and Reduction (Oxford: Blackwell, 2006)

xxxiv Se Dennett, Consciousness Explained; Dennett, Content and Consciousness, 2. utg. (New York: Routledge \& Kegan Paul, 1986).

xxxv Jf. Dennett, Breaking the Spell: Religion as Natural Phenomenon (New York: Penguin, 2006). 
xxxvi Se Kandel \& Squire, «Neuroscience», 1114.

xxxvii Kandel \& Squire, «Neuroscience», 1118.

xxxviii Se Edmund Husserl, Die Krisis der europäischen Wissenschaften und die transzendentale Phänomenologie, 3. utg. (Hamburg: Meiner, 1996), 49-64.

xxxix Husserl, Krisis, 51.

${ }^{x l}$ Husserl, Krisis, 64.

xli Se Dan Zahavi, Husserl's Legacy, 147.

xlii Til distinksjonen mellom forklaring og forståelse, se Georg Henrik von Wright, Explanation and Understanding, 2. utg. (London: Routledge, 1975).

xliii Zahavi, Husserl's Legacy, 186

xliv Se Zahavi, Husserl's Legacy, 150-2. Uttrykket 'kritisk realisme' brukes innenfor ulike disipliner som ikke skal diskuteres her. Jeg begrenser meg derfor til Husserls bruk 'krisis' for den fenomenologiske anvendelsen av termen.

xlv Mer om dette i: Dan Zahavi, Self-awareness and Alterity: A Phenomenological Investigation. Evanston: Northwestern University Press, 1999

xlvi Sml. Zahavi, Husserl's Legacy, 193-5. Se også Francisco J. Varela, Evan Thompson \& Eleanor Rosch, The Embodied Mind: Cognitive Science and Human Experience, rev. utg. (Cambridge MA: MIT Press, 2017) og Shaun Gallagher \& Dan Zahavi, The Phenomenological Mind, 2. utg. (London: Routledge, 2013)

xlvii Cathérine Malabou, What Should We Do with Our Brain? Tr. Sebastian Rand (New York: Fordham University Press, 2008). Boken er nå også tilgjengelig på norsk: Hva skal vi gjøre med hjernen vår? (Moss: H/O/F, 2017), overs. Kaja Jenssen Rathe.

xlviii Malabou, What Should We Do, 40-46.

xlix Malabou, What Should We Do, 46-54. Se også Malabou, The New Wounded: From Neurosis to Brain Damage (New York: Fordham University Press, 2012).

'Malabou, What Should We Do, 78-82.

Ii Se Malabou, Before Tomorrow: Epigenesis and Rationality, tr. Carolyn Shread (London: Polity, 2016), 16-19.

lii Se Malabou, Before Tomorrow, 50-52; 85-86.

liii Sml. Malabou, Before Tomorrow, 155-74.

liv Malabou, Before Tomorrow, 158. Sml. den interessante artikkelen om begrepet epigenese av $\varnothing$ ystein Brekke: "On the Subject of Epigenesis: An interpretive Figure in Paul Ricoeur" i Impossible Time, red. MT Mjaaland, P Stoellger og UH Rasmussen (Tübingen: Mohr Siebeck, 2013), 73-82.

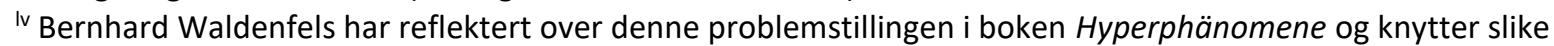
transcenderende erfaringer til religion. Bernhard Waldenfels, Hyperphänomene (Berlin: Suhrkamp, 2012), 3536. Waldenfels avviser den abstrakte forståelsen av transcendens som peker «hinsides» vår erfaringsverden slik Kant og senere filosofer har definert det. Transcendens handler snarere om overskridende erfaringer, hevder han, i betydningen intensivering, fortetning eller Überstieg. Det er en slik forståelse av transcendens jeg forutsetter her.

Ivi Se Robert N. McCauley, Philosophical Foundations of the Cognitive Science of Religion (London: Bloomsbury, 2017); Anne Runehov, Sacred or Neural? (Göttingen: V\&R, 2007); Aku Visala, Naturalism, Theism, and the Cognitive Study of Religion (Farnham: Ashgate, 2011) og Luther H Martin og Donald Wiebe (eds.), Religion Explained? (London: Bloomsbury, 2017).

Ivii Se Visala, Naturalism og Anne Runehov, The Human Being, the World and God (Berlin: Springer, 2016)

Iviii Dette går også tydelig frem av debatten mellom Dennett og Plantinga i boken: Science and Religion - Are They Comptible? (Oxford: Oxofrd University Press, 2010).

lix https://www.webmd.com/add-adhd/guide/adhd-how-common\#1 Tilsvarende tall i Norge er rundt $3 \%$, i Frankrike under $0,5 \%$.

Ix Per Brodal, “Nevrokulturell imperialism”, Tidsskriftet 2018. DOI: 10.4045/tidsskr.18.0707.

Sammendrag

The neurosciences have made significant progress over the last decades, but new discoveries raise philosophical and theological problems that remain unresolved: How can we understand time and space, consciousness and meaning; how can we perceive religious experiences and faith in God if scientific explanations of the world are dominated by neurons and synapses? Two models of explanation dominate the emerging field of neurophilosophy: (i) naturalism, represented by philosophers such as Daniel Dennett and Patricia \& Paul 
Churchland, and (ii) phenomenology, represented by philosophers such as Cathérine Malabou and Dan Zahavi. I will discuss the two approaches and their ability to explain recent developments in neuroscience, where I draw upon examples from the discovery of place and grid cells that resulted in the Nobel Prize in physiology or medicine to O'Keefe, Moser \& Moser in 2014. A key question is how to explain the experience of transcendence as related to the perception of time and space within and through the neurons.

Keywords: Neuroscience, life science, phenomenology, naturalism, space, time, God Nøkkelord: Nevrovitenskap, livsvitenskap, fenomenologi, naturalisme, rom, tid, Gud 